ISSN: 1858-3385, EISSN: 2549-7006

GASTER Vol. 17 No. 2 Agustus 2019

\title{
Peningkatan Kualitas Hidup Pasien Diabetes Mellitus dengan Metode Relaksasi
}

\author{
Erika Dewi Noorratri, Ari Sapti Mei Leni \\ STIKES 'Aisyiyah Surakarta \\ Email: erika.dzikra2016@gmail.com \\ Doi : https://doi.org/10.30787/gaster.v17i2.358 \\ Received: February 2019 | Revised: April 2019 | Accepted: April 2019
}

\begin{abstract}
ABSTRAK
Latar Belakang: Diabetes Mellitus (DM) merupakan penyakit gangguan metabolik menahun yang diakibatkan oleh pankreas yang tidak memproduksi secara cukup insulin atau insulin yang diproduksi secara efektif tidak dapat digunakan oleh tubuh. Pada tahun 2012 Prevalensi diabetes melitus tergantung insulin di Provinsi Jawa Tengah sebesar 0,06 lebih rendah dibanding tahun 2011 (0,09\%). Sukoharjo pada tahun 2014 melaporkan sebanyak 5.413 kasus meningkat dibandingkan kasus DM pada tahun 2013 sebanyak 5.052 kasus. Kualitas hidup sangat penting didalam mengelola sebuah penyakit, seperti penyakit DM. Kualitas hidup pasien DM dapat ditingkatkan melalui metode relaksasi. Tujuan Penelitian: Menganalisis peningkatan kualitas hidup pasien DM melalui metode relaksasi. Metode: metode Quasi Eksperimental. Rancangan penelitian pre-post group test design with control group.sampel penelitian ada 25 kelompok perlakuan dan 25 kelompok kontrol. Hasil: menunjukkan bahwa pada kelompok perlakuan kualitas hidup pasien DM terjadi peningkatan secara signifikan dari pertemuan pertama sampai keenam, dengan nilai $p=0,000(p<0,05)$. Perlakuan relaksasi secara signifikan berpengaruh meningkatkan kualitas hidup pasien diabetes melitus, perlakuan kontrol tidak signifikan meningkatkan kualitas hidup pasien diabetes melitus dan perlakuan relaksasi lebih baik dalam meningkatkan kualitas hidup dibandingkan kontrol. Kesimpulan: Perlakuan relaksasi secara signifikan berpengaruh signifikan meningkatkan kualitas hidup pasien diabetes melitus.
\end{abstract}

Kata Kunci : DM; Kualitas hidup; Metode Relaksasi

\section{ABSTRACT}

Background: Diabetes Mellitus (DM) is a chronic metabolic disorder is caused by the pancreas that does not produce enough insulin or effectively produced insulin that cannot be used by the body. In 2012 the prevalence of insulin-dependent diabetes mellitus in Central Java Province was 0.06 lower than in 2011 (0.09\%). In Sukoharjo 2014 reported that 5,413 cases had increased compared to DM cases in 2013 with 5,052 cases. Quality of life is very important in managing a disease, such as DM disease. The Quality of life DM patients can be improved through relaxation 
methods. Objectives: The are Analyzing the improvement of the quality of life DM patients through relaxation methods. Method: Quasi Experimental of method. The research design was pre-post group test design with control group. There were 25 treatment groups and 25 control groups. Results: The showed in the treatment group the quality of life of DM patients had a significant increase from the first to the sixth meeting, with a value of $p=0,000(p<0.05)$. The relaxation treatment significantly affected the quality of life of patients with diabetes mellitus, the control treatment did not significantly improve the quality of life of patients with diabetes mellitus and the relaxation treatments were better at improving quality of life than contol groups. Conclusion: The relaxation treatment significantly affected significantly the quality of life of patients with diabetes mellitus.

Keywords: DM; Quality of life; Relaxation

\section{PENDAHULUAN}

Diabetes Mellitus (DM) merupakan penyakit gangguan metabolik menahun yang diakibatkan oleh pankreas yang tidak memproduksi secara cukup insulin atau insulin yang diproduksi secara efektif tidak dapat digunakan oleh tubuh (Kemenkes. 2014).

WHO(1985) mengklasifikasikan penderita DM dalam lima golongan klinis, yaitu DM Tergantung Insulin (DMTI), DM Tidak Tergantung Insulin (DMTTI), DM karena Toleransi Glukosa Terganggu (TGT), DM berkaitan dengan malnutrisi (MRDM), dan DM karena kehamilan (GDM). Di Indonesia, yang terbanyak adalah DM tidak tergantung insulin yang akan muncul pada usia di atas 40 tahun. DM dapat menjadi penyebab berbagai penyakit seperti stroke, hipertensi, gagal ginjal, katarak, jantung koroner, glaukoma, kerusakan retina mata yang dapat membuat buta, gangguan fungsi hati, luka yang lama sembuh mengakibatkan infeksi yang dapat menyebabkan kaki diamputasi dan impotensi.

Pada tahun 2012 Prevalensi diabetes melitus tergantung insulin di Provinsi Jawa Tengah sebesar 0,06 lebih rendah dibanding tahun $2011(0,09 \%)$. Prevalensi tertinggi adalah Kabupaten Semarang sebesar 0,66\%. Sedangkan prevalensi kasus DM tidak tergantung insulin lebih dikenal dengan DM tipe II, pada tahun 2012 mengalami penurunan dari $0,63 \%$ menjadi $0,55 \%$. Pada tahun 2012 Kota Magelang merupakan kota dengan Prevalensi tertinggi sebesar 7,93\%. (Profil Jateng. 2012).

Sukoharjo merupakan kota dengan pasien DM banyak. Puskesmas Sukoharjo melaporkan pada tahun 2012 penderita DM sebanyak 4.741 
ISSN: 1858-3385, EISSN: 2549-7006

GASTER Vol. 17 No. 2 Agustus 2019

kasus, hal ini menurun dibandingkan pada tahun 2011 sebanyak 10.102 kasus DM. (Profil Kesehatan Kabupaten Sukoharjo, 2012). Pada tahun 2013 sebanyak 5.052 kasus meningkat dari tahun 2012 sebesar 4.741 kasus DM. (Profil Kesehatan Kabupaten Sukoharjo, 2013 ) Pada tahun 2014 melaporkan sebanyak 5.413 kasus meningkat dibandingkan kasus DM pada tahun 2013 sebanyak 5.052 kasus. (Profil Kesehatan Kabupaten Sukoharjo, 2014 )

Kualitas hidup sangat penting didalam mengelola sebuah penyakit, seperti penyakit DM. Kualitas hidup pasien DM perlu ditingkatkan karena orang dengan penyakit DM kualitas hidupnya terganggu, seperti mereka malas untuk melakukan pekerjaan sehar-hari. Karena merasa badannya mudah lelah dan tidak bersemangat. Pada pasien DM banyak masalah yang dihadapi, diantaranya masalah dalam mengelola penyakit, melakukan diet DM, masalah gangguan reproduksi, masalah yang menyerang berbagai organ tubuh, masalah dalam kehidupan seharihari, dan masalah dalam kualitas hidupnya. Saya memilih untuk meneliti tentang kualitas hidup pasien DM karena saya melihat masalah pada kualitas hidup pasien DM, kurangnya semangat dalam menjalani kehidupan sehari- hari, masalah kualitas hidup pasien DM dia malas untuk bekerja. Pasien DM mempunyai pandangan terhadap dirinya bahwa hidup mempunyai tujuan dan harapan dan mereka menganggap posisinya dalam kehidupan sehari-hari mengalami masalah, karena penyakit yang dialaminya, mereka tidak semangat bekerja seperti yang lainnya. Kualitas hidup merupakan persepsi individu terhadap posisi mereka dalam kehidupan dan sistem nilai konteks budaya dimana mereka hidup dalam hubungannya dengan tujuan individu harapan, standar dan perhatian. (WHO, 2004 dalam Yusra Aini. 2011).

Pasien DM dalam menjalani hidupnya perlu adanaya terapi selain terapi farmakologis, obatobatan tetapi juga terapi non-farmakologis. Terapi non-farmakologis yang bisa digunakan untuk meningkatkan kualitas pasien DM dengan menggunakan metode relaksasi. Dengan menggunakan metode relaksasi pasien DM akan merasa tenang, relax, merasa mampu mengontrol emosi yang dapat meningkatkan kualitas hidupnya.

Di Desa Sukoharjo wilayah kerja Puskesmas Sukoharjo pasien DM mempunyai masalah dalam berbagai hal. Salahsatunya pasien tersebut mempunyai masalah dalam hal 
kualitas hidup. Metode Relaksasi diharapkan dapat membantu kualitas hidup pasien DM. Hal inilah yang mendorong untuk dilakukan penelitian tentang peningkatan kualitas hidup pasien diabetes mellitus dengan metode relaksasi di Desa Sukoharjo wilayah kerja Puskesmas Sukoharjo.

\section{BAHAN DAN METODE}

Penelitian ini menggunakan metode Quasi Eksperimental. Rancangan penelitian pre-post group test design with control group. Populasi yang digunakan adalah semua pasien yang menderita diabetes mellitus di Puskesmas Sukoharjo. Penelitian ini menggunakan sampel 50 orang, tebagi menjadi 2 yaitu 25 orang untuk kelompok perlakuan dan 25 orang untuk kelompok kontrol, cara menentukan sampel dengan menggunakan rumus Slovin.

\section{Penelitian dilakukan di Puskesmas} Sukoharjo dan Puskesmas Grogol pada bulan Mei sampai Juni 2017. Variabel Variabel bebas dalam penelitian ini adalah metode relaksasi. Metode relaksasi menggunakan alat ukur dengan lembar obsevasi, dengan hasil ukur baik dan buruk. Dikatakan skor baik apabila mendapat skor 2, apabila semua langkah metode relaksasi dilakukan semua. Buruk skor 1, apabila langkah metode relaksasi tidak dilakukan semua.

Variabel terikat dalam penelitian ini adalah kualitas hidup pasien diabetes mellitus yang meliputi diet, olahraga, memeriksa kadar glukosa darah, mengatur obat, mengontrol penyakit, perawatan dan pengobatan yang ada. Diet pasien DM yaitu bagaimana pasien DM mampu mengatur pola makan, sehingga kadar glukosa dalam darah tidak naik, dan dengan diet mampu mengontrol kadar gula darah. Olahraga dilakukan untuk menjadikan badan sehatdan bugar, pasien DM dengan melakukan olahraga secara teratur membuat badan sehat. kadar glukosa dalam darah tidak naik, karena dengan olahraga badan bergerak dan gula tidak menumpuk dalam darah, karena dijadikan sumber energi. Memeriksa kadar gula darah dilakukan secara teratur untuk mengetahui normal tidaknya kadar gula darah dalam tubuh. Mengatur obat dilakukan agar pasien DM tidak sembarangan minum obat, dan minum obat sesuai dengan dosis yang dianjurkan oleh dokter. Mengontrol penyakit pada pasien DM dengan selalu memperhatikan kadar gula darah, rutin cek kadar gul darah, teratur periksa ke dokter untuk menghindari terjadinya komplikasi pada pasien DM. Pasien DM dengan melakukan perawatan dan pengobatan 
secara teratur dan tepat menjadikan pasien DM terhindar dari kompilkasi penyakit. Instrumen penelitian yang digunakan menggunakan kuesioner Diabetes Quality of Life, dengan mengisi kuesioner yang berupa pertanyaan, makin tinggi skor yang diperoleh makin besar tingkat kualitas hidup pasien diabetes melitus.

\section{HASIL DAN PEMBAHASAN}

Tabel.1.1 Distribusi frekuensi usia

\begin{tabular}{lcc}
\hline \multicolumn{1}{c}{ Kategori } & frekuensi & persentase (\%) \\
\hline interval 1 & 10 & 20.0 \\
interval 2 & 29 & 58.0 \\
interval 3 & 11 & 22.0 \\
Total & 50 & 100 \\
\hline
\end{tabular}

Tabel. 1.2 Distribusi frekuensi jenis kelamin

\begin{tabular}{lcc}
\hline \multicolumn{1}{c}{ Kategori } & frekuensi & persentase(\%) \\
\hline Perempuan & 29 & 58.0 \\
laki-laki & 21 & 42.0 \\
Total & 50 & 100 \\
\hline
\end{tabular}

Tabel 1.3 Distribusi frekuensi status pernikahan

\begin{tabular}{lcc}
\hline \multicolumn{1}{c}{ Kategori } & frekuensi & persentase(\%) \\
\hline Menikah & 45 & 90.0 \\
belum menikah & 5 & 10.0 \\
Total & 50 & 100 \\
\hline
\end{tabular}

Tabel 1.4 Distribusi frekuensi jenis pekerjaan

\begin{tabular}{lcc}
\hline \multicolumn{1}{c}{ Kategori } & frekuensi & persentase(\%) \\
\hline tidak bekerja & 5 & 10.0 \\
PNS & 4 & 8.0 \\
Petani & 22 & 44.0 \\
Wiraswasta & 19 & 38.0 \\
Total & 50 & 100 \\
\hline
\end{tabular}

Tabel 1.5 Distribusi frekuensi pendidikan responden

\begin{tabular}{lcc}
\hline \multicolumn{1}{c}{ Kategori } & frekuensi & persentase(\%) \\
\hline tidak sekolah & 2 & 4.0 \\
SD & 20 & 40.0 \\
SMP & 15 & 30.0 \\
SMA & 8 & 16.0 \\
perguruan tinggi & 5 & 10.0 \\
Total & 50 & 100 \\
\hline
\end{tabular}

Tabel 1.6 Distribusi frekuensi pendapatan

\begin{tabular}{lcc}
\hline \multicolumn{1}{c}{ Kategori } & frekuensi & persentase (\%) \\
\hline Interval 2 & 36 & 72.0 \\
Interval 3 & 7 & 14.0 \\
Interval 4 & 7 & 14.0 \\
Total & 50 & 100 \\
\hline
\end{tabular}

Tabel 1.7 Distribusi frekuensi penyakit lain

\begin{tabular}{lcc}
\hline \multicolumn{1}{c}{ Kategori } & frekuensi & persentase(\%) \\
\hline Ya & 17 & 34.0 \\
Tidak & 33 & 66.0 \\
Total & 50 & 100 \\
\hline
\end{tabular}


Tabel 2.1 Distribusi frekuensi jarak ke fasilitas kesehatan

\begin{tabular}{lcc}
\hline \multicolumn{1}{c}{ Kategori } & Frekuensi & persentase(\%) \\
\hline interval 1 & 5 & 10.0 \\
interval 2 & 3 & 6.0 \\
interval 3 & 20 & 40.0 \\
interval 4 & 6 & 12.0 \\
interval 5 & 16 & 32.0 \\
Total & 50 & 100 \\
\hline
\end{tabular}

Karakteristik responden menyatakan bahwa jenis kelamin yang paling banyak adalah perempuan 29 (58\%). Penelitian lain yang menyatakan bahwa jenis kelamin perempuan menunjukkan bahwa perempuan lebih berisiko terkena Diabetes Mellitus tipe2 dibandingkan laki-laki. Perempuan secara fisik lebih berisiko mengidap diabetes mellitus tipe II karena memiliki peluang peningkatan indeks masa tubuh yang lebih besar, pascamenopause membuat distribusi lemak tubuh mudah terakumulasi akibat proses hormonal dan sindroma siklus bulanan, (Taluta, dkk. 2014).

Menurut Gerrich yang dikutip oleh Indriyani, P, dkk. (2007) diabetes mellitus lebih banyak terjadi pada wanita pada usia 40 - 70 tahun, tetapi pada umur yang lebih muda frekuensi diabetes lebih besar pada laki-laki, dipicu adanya persentase timbunan lemak pada badan wanita lebih besar dibandingkan dengan timbunan lemak laki-laki (Ferannini Elle, 2003) dalam Indriyani, P, dkk. (2007).

Hasil penelitian menyatakan bahwa umur pasien Diabetes Mellitus terbanyak pada usia 50 sampai 59 tahun sebanyak 29 (58\%). Pada usia tersebut seseorang sudah memasuki usia pertengahan. Sesuai dengan penelitian Balakrishnan (2013) seseorang akan mengalami 5 kali lebih besar resiko terkena DM pada usia diatas 50 tahun dibandingkan dengan seseorang yang usia 20-30 tahun.

Hasil penelitian menyatakan status pernikahan pasien Diabetes Mellitus terbanyak pada status nikah. Sesuai dengan penelitian dari Irma,B dan Krisnawati tahun 2014 menyatakan bahwa wanita dewasa yang berstatus kawin mempunyai peluang sekitar 3,2 kali lebih besar untuk mengalami DM dibandingkan dengan wanita dewasa yang belum menikah.

Pendidikan pasien Diabetes Mellitus di Puskesmas Sukoharjo paling banyak pendidikan rendah (tidak sekolah, SD dan SMP) ada 37 (74\%). Pasien dengan pendidikan yang rendah perlu diberikan penyuluhan dan pendidikan kesehatan untuk meningkatkan 
pengetahuan, Pasien yang lebih banyak mengalami kegagalan dalam hal pengobatan memiliki pengetahuan yang kurang dibanding pasien dengan pendidikan yang baik, begitu juga dengan kualitas hidup pasien Diabetes Mellitus juga akan berpengaruh, karena waktu untuk pengobatan untuk mendapatkan perawatan dan yang lainnya akan berkurang jika pengetahuan kurang. (Rusadi, M., dkk. 2012).

Hasil penelitian diketahui bahwa pasien Diabetes Mellitus di Puskesmas Sukoharjo paling banyak bekerja ada 45 (90\%). Orang yang bekerja mempunyai beban yang tinggi, baik beban fisik maupun beban pikiran. Penelitian menyatakan bahwa orang yang bekerja kurang istirahat dibanding orang yang tidak bekerja. ( Erawatyningsih, E.dkk. 2009). Hal tersebut menyebabkan seseorang akan mengalami kualitas hidup yang berbeda beda, karena waktu yang dibutuhkan untuk meningkatkan kualitas hidup banyak tersita untuk bekerja.

Hasil penelitian menunjukkan bahwa pasien DM terbanyak pada seseorang yang mempunyai pendapatan tinggi. Sesuai dengan penelitian pada kondisi ekonomi, responden yang mandiri memiliki ekonomi yang mampu dimana responden mampu memenuhi kebutuhan. Sehingga ingin makan apa saja terpenuhi dan lupa untuk menjaga pola makan, yang bisa menyebabkan terjadinya DM. Hasil penelitian ini sesuai dengan penelitian yang dilakukan oleh Darmojo dkk (2004) dalam (Rinajumita, 2011).

Hasil penelitian menunjukkan bahwa seseorang dengan mempunyai penyakit lain tidak banyak menderita penyakit DM, berbeda dengan penelitian dari Miharja (2009) yang dikutip oleh Iin, M (2013) menyatakan bahwa seseorang yang mengalami hipertensi dapat membuat sel tidak sensitif terhadap insulin (resisten insulin). Seseorang dengan penyakit hipertensi akan mudah terkena DM.

Hasil penelitian menunjukkan bahwa jarak yang cukup jauh yang paling banyak. Hal ini menunjukkan bahwa akses yang cukup dekat dengan fasilitas kesehatan akan mempermudah partisipan dalam melakukan pemantauan glukosa darah. Waktu dan juga jarak tempuh ini menjadi faktor yang memengaruhi keteraturan kontrol kadar gula darah pasien DM (Albherta.2011) yang dikutip oleh Rizana, F.dkk. (2017). 
Tabel 2.2 Statistik deskriptif pada kelompok perlakuan

\begin{tabular}{lccccccc}
\hline $\begin{array}{l}\text { Statis- } \\
\text { tik }\end{array}$ & pre & post1 & post2 & post3 & post4 & post5 & $\begin{array}{c}\text { pening- } \\
\text { katan }\end{array}$ \\
\hline $\mathrm{N}$ & 25 & 25 & 25 & 25 & 25 & 25 & 25 \\
Mean & 15.72 & 18.52 & 19.96 & 20.8 & 22.76 & 23.32 & 7.6 \\
$\begin{array}{l}\text { Std. } \\
\begin{array}{l}\text { Devia- } \\
\text { tion }\end{array}\end{array}$ & 4.3062 & 3.30555 & 3.25935 & 2.54951 & 1.50776 & 1.1804 & 3.3665 \\
Md & 17 & 19 & 21 & 22 & 23 & 24 & 6 \\
Min & 8 & 12 & 13 & 16 & 19 & 21 & 3 \\
Max & 21 & 23 & 24 & 24 & 24 & 24 & 14 \\
\hline
\end{tabular}

Tabel 2.3 Statistik deskriptif pada kelompok kontrol

\begin{tabular}{lccccccc}
\hline $\begin{array}{c}\text { statis- } \\
\text { tik }\end{array}$ & pre & post1 & post2 & post3 & post4 & post5 & $\begin{array}{c}\text { pening- } \\
\text { katan }\end{array}$ \\
\hline $\mathrm{N}$ & 25 & 25 & 25 & 25 & 25 & 25 & 25 \\
Mean & 15.28 & 15.28 & 15.12 & 15.12 & 15.12 & 15.08 & -0.2 \\
$\begin{array}{l}\text { Std. } \\
\begin{array}{l}\text { Devia- } \\
\text { tion }\end{array}\end{array}$ & 1.90438 & 1.90438 & 1.98578 & 1.94336 & 1.94336 & 1.97737 & 0.5 \\
$\begin{array}{l}\text { Me- } \\
\text { dian }\end{array}$ & 15 & 15 & 15 & 14 & 14 & 14 & 0 \\
Min & 12 & 12 & 12 & 12 & 12 & 12 & -2 \\
Max & 19 & 19 & 19 & 19 & 19 & 19 & 0 \\
\hline
\end{tabular}

Hipotesis ada peningkatan kualitas hidup pasien diabetes mellitus dengan metode relaksasi pada pasien kelompok intervensi di terima. Penelitian yang dilakukan pada metode relaksasi yaitu melalui kuesioner kualitas hidup yang diberikan pada pasien diabetes mellitus dengan melibatkan pasien secara mandiri dan terarah dengan pengobatan yang intensif mendapatkan hasil mampu meningkatkan kualitas hidup pasien diabetes mellitus, langkah-langkah intervensi pemberian metode relaksasi pada kelompok perlakuan pertama mengkaji kualitas hidup pasien diabetes mellitus kemudian membuat kesepakatan dengan pasien diabetes mellitus berkenaan dengan proses perlakuan metode relaksasi, setelah itu melakukan prosedur tindakan metode relaksasi. Varvogli (2011) dalam Nurrohmah, L (2014) menyatakan bahwa relaksasi membantu tubuh untuk rileks dari perintah autosugesti sehingga dapat mengendalikan pernafasan, denyut jantung, suhu tubuh dan tekanan darah. Standar latihan relaksasi meliputi imajinasi visual dan mantramantra verbal yang membuat tubuh merasa hangat, berat dan santai.

Varvogli dan Darviri (2011) dalam Hidayat dan Ekaputri (2015) menyebutkan relaksasi nafas dalam sangat efektif dalam mengatasi ansietas dan stres. Teknik relaksasi ini cocok digunakan pada klien dengan penyakit darah tinggi, diabetes, obesitas dan sakit kepala, jantung, maupun stroke. Latihan tarik napas dalam merupakan salah satu teknik relaksasi yang bertujuan untuk memberikan efek relaksasi pada klien. Hasil penelitian yang dilakukan oleh Widiarti (2013) dalam Hidayat dan Ekaputri (2015) menunjukkan bahwa 
ansietas secara efektif berkurang dengan terapi relaksasi. Hal tersebut sesuai juga berdasarkan Fernandes (2014) dalam Hidayat dan Ekaputri (2015) menyebutkan bahwa relaksasi nafas dalam dapat mendorong pertukaran oksigen yang lebih banyak dan pengeluaran karbon dioksida dalam tubuh. Nafas dalam dapat membuat detak jantung menjadi lambat, tekanan darah menjadi stabil dan ansietas menurun.

Lejeune (2007) dalam Hidayat dan Ekaputri (2015) dalam bukunya menyebutkan bahwa teknik relaksasi yang dilakukan hanya mengatasi secara fisik saja pada ansietas dan sifatnya lebih kepada lari dari kecemasan yang dialami. Teknik relaksasi bertujuan mencapai keadaan relaksasi menyeluruh, mencakup keadaan relaksasi secara fisiologis, secara behavioral dan secara kognitif. Secara fisiologis, keadaan relaksasi ditandai dengan penurunan frekuensi denyut jantung (sampai mencapai 24 kali per menit), penurunan frekuensi nafas (sampai 4-6 kali per menit), penurunan kadar epinefrin dan non epinefrin, metabolisme menurun, vasodilatasi dan peningkatan temperatur pada extermitas, penurunan tekanan darah, dan penurunan ketegangan otot oleh Rahmayati (2010) dalam Hidayat dan Ekaputri (2015).

Pemberian teknik relaksasi nafas dalam pada pasien akan menurunkan ketegangan sehingga mencapai keadaan rileks, mengencangkan serta mengendurkan kumpulan otot secara bergantian sehingga merasakan perbedaan antara relaksasi dan ketegangan serta dapat memusatkan perhatian pada teknik pernafasan. Ghofur \& Purwoko, (2012) dalam Hidayat dan Ekaputri (2015).

Hasil penelitian setelah dilakukan uji analisis dapat disimpulkan bahwa pada kelompok kontrol tidak ada perubahan.

\section{SIMPULAN DAN SARAN}

Perlakuan relaksasi secara signifikan berpengaruh signifikan meningkatkan kualitas hidup pasien diabetes melitus, perlakuan kontrol tidak signifikan meningkatkan kualitas hidup pasien diabetes melitus dan perlakuan relaksasi lebih baik dalam meningkatkan kualitas hidup dibandingkan kontrol. 


\section{DAFTAR PUSTAKA}

Kemenkes.2014.http://www.depkes.go.id/resources/download/pusdatin/infodatin/infodatindiabetes.pdf

Profil Kesehatan Kabupaten Sukoharjo, 2012.http://www.depkes.go.id/resources/download/ profil/PROFIL_KAB_KOTA_2012/3311_Jateng_Kab_Sukoharjo_2012.pdf

Profil Kesehatan Kabupaten Sukoharjo, 2013. http://www.depkes.go.id/resources/download/ profil/PROFIL_KAB_KOTA_2013/3311_Jateng_Kab_Sukoharjo_2013.pdf

Profil Kesehatan Kabupaten Sukoharjo, 2014. http://www.depkes.go.id/resources/download/ profil/PROFIL KAB KOTA 2014/3311 Jateng Kab Sukoharjo 2014.pdf

Yusra Aini. 2011. Hubungan antara dukungan keluarga dengan kualitas hidup pasien diabetes mellitus tipe 2 di Poliklinik Penyakit Dalam Rumah Sakit Umum Pusat Fatmaawati Jakarta. Tesis. Universitas Indonesia.

Taluta, Y. P.,Mulyadi, H. R., S. (2014). Hubungan tingkat kecemasan dengan mekanisme koping pada pendeerita diabetes mellitus tipe II di poliklinik penyakit dalam rumah sakit umum daerah Tobelo kabupaten Halmahera Utara. http://ejournal.unsrat.ac.id/index.php/jkp/ $\underline{\operatorname{article} / \text { view/4059 }}$

Indriyani, P. Suprayitno, H dan Santoso, A. (2007). Pengaruh latihan fisik; senam aerobik terhadap penurunan kadar gula darah pada penderita dm tipe 2 Di wilayah puskesmas bukateja purbalingga. Media Ners, Volume 1, Nomor 2.

Balakrishnan V, Jayadevan S, Jayakumari M, Sudha B V. (2013). Risk Factors Of Type 2 Diabetes Mellitus In The Rural Population Of North Kerala, India: A Case Control Study. Original Research Article. India. Diabetologia Croatica.

Irma N, Krisnawati B. (2014). Prevalensi dan Faktor Risiko Kejadian Diabetes Mellitus Pada wanita Dewasa di Indonesia. Departemen Epidemiologi Fakultas Kesehatan Masyarakat Universitas Indonesai. Jakarta.UI

Rusadi, M, Junaidi, dan Sri, S.. (2012). Hubungan Pengetahuan dengan Kegagalan Pengobatan Tuberculosis di Puskesmas Antang Kecamatan Manggala Kota Makassar. Vol.1 No.1 Tahun 2012. ISSN : 2307 2531. Universitas Hasanudin Makasar 
ISSN: 1858-3385, EISSN: 2549-7006

GASTER Vol. 17 No. 2 Agustus 2019

Erawatyningsih, E. Purwanta dan Heru, S. (2009). Faktor-Faktor yang Mempengaruhi Ketidakpatuhan Berobat pada Pasien Tuberculosis Paru. Berita Kedokteran Masyarakat, Vol. 25, No. 3, September 2009

Rinajumita, 2011. Faktor-faktor yang berhubungan dengan kemandirian lansia Di wilayah kerja puskesmas lampasi Kecamatan payakumbuh utara Tahun 2011. Jurnal Program Studi Ilmu Kesehatan Masyarakat.

Iin, M. (2013). Hubungan Kadar Gula Darah Dengan Hipertensi Pada Pasien Diabetes Melitus Tipe 2 Di Rumah Sakit Umum Daerah Karanganyar.Naskah publikasi. UMS

Rizana, F, Diah L, dan Angki P. (2017). Faktor Penghambat dan Pendukung Pasien diabetes Mellitus dalam Melakukan Pemeriksaan Glukosa Darah. Artikel Penelitian. Global Medical and Health Communication.

Hidayat, A,y. dan Ekaputri, Y.S. (2015) Penerapan Teknik Napas Dalam Pada Pasien Diagnosis Keperawatan Ansietas Dengan Diabetes Mellitus Serta Tubercolosis Paru Di Ruangan Umum Rsmm Bogor. Jurnal Keperawatan Jiwa . Volume 3, No. 2, November 2015 http:// www.depkes.go.id/resources/download/profil/PROFIL_KES_PROVINSI 2012/13 Profil Kes.Prov.JawaTengah_2012.pdf

Nurrohmah, L. (2014). Efektivitas pelatihan relaksasi untuk menurunkan stres penderita Diabetes mellitus tipe 2 .Tesis. UMS

140 Peningkatan Kualitas Hidup Pasien Diabetes Mellitus .... 